\title{
THE ROLE OF HOSPICE CAREGIVERS IN CARING FOR FAMILIES INFECTED WITH, OR AFFECTED BY, HIV/AIDS
}

\section{Nerina Bester, Alida Herbst}

\section{INTRODUCTION}

Hospice TLC is the name of a non-profit organization (NPO) rendering services in the Kokstad area situated in the southern region of KwaZulu-Natal, South Africa. Hospice TLC has been in operation since June 2006 and its main focus is to render holistic palliative and frail care to all patients in their area of operation. In this article the focus will be on the role Hospice TLC caregivers can play in meeting the bio-psychosocial needs of families infected or affected by HIV and AIDS in the Kokstad area. Through their contact with frail and terminally ill patients the caregivers have access to their families, affording them an opportunity to identify and meet some of the bio-psychosocial needs of the families.

This article reports on the results of a qualitative study exploring caregivers' perceptions of their roles in dealing with HIV-infected or affected families in the Kokstad area. Data were obtained by means of a series of focus group sessions with caregivers and the analysis utilised Creswell's analytical spiral and Tesch's approach.

\section{AIM AND OBJECTIVES}

The overarching aim of this study was to undertake a critical investigation of the role that the Hospice TLC caregivers play in the lives of families infected with, or affected by, HIV or AIDS. The specific objective applicable to this article is to explore, through focus group discussions, how hospice caregivers perceive their training, tasks, roles and scope of practice in relation to the psychosocial needs of families infected or affected by HIV and AIDS.

\section{RESEARCH METHODOLOGY}

The goal of this qualitative study is to undertake a critical investigation regarding the role Hospice TLC caregivers fulfil in the lives of families infected with, or affected by, HIV and AIDS in the Kokstad area and how service rendering to these families could be improved. The nature of this study is both descriptive and explanatory (Fouché \& De Vos, 2007:106) by focusing on the descriptions and explanations of the roles of caregivers in the lives of people infected with, or affected by, HIV and AIDS.

Data were collected by asking empirical questions (Mouton, 2005:53, 54) during five focus group sessions (Greeff, 2007:286) and by means of a literature review (Fouché \& Delport, 2007:76). Ethical aspects such as permission from Hospice TLC and Child Welfare South Africa, confidentiality and voluntary participation were taken into account in this study (Strydom, 2000:64).

The total population of nine caregivers employed by Hospice TLC participated in the focus group sessions. The researcher made use of an interpreter, who assisted with the recording of data and with the translation to minimise the effect of misunderstanding because of language barriers. The caregivers are all Xhosa first-language speakers.

In the interpretation and analysis of the data obtained, Tesch's analytical process was used (Tesch, 1990:77). The research was further informed by an extensive literature study dealing with the three questions discussed during the focus group sessions against the background of 
Circles of Support (Smart, 2003:43), where community involvement and the utilisation of community resources form an integral part of the helping relationship (Egan, 1994).

\section{LITERATURE REVIEW}

\section{The impact of HIV and AIDS on individuals, families and communities}

HIV and AIDS are impacting on communities worldwide and Kokstad is no exception. According to Smit (2007:1), 19 million people could have died globally by the end of the $20^{\text {th }}$ century as a result of HIV and AIDS. The impact on families as a result is devastating. The orphan population could exceed 13 million by 2010. Seemingly $70 \%$ of the 34 million people infected with, or affected by, HIV and AIDS are living in sub-Saharan Africa and a projection of 44 million orphans under the age of 15 is shocking.

South Africa is one of the worst affected countries in the world and the KwaZulu-Natal province has one of the highest infection growth rates recorded at antenatal clinics, rising from 19.9\% in 1996 to 36.5\% in 2005 (Avert, 2005; Van Wyk \& Lemmer, 2007:241). This is also true of the Kokstad community, which consists of 34000 registered voters. The census of 2001 counted 56537 people in the greater Kokstad area (STATSSA, 2008). A person diagnosed with HIV or AIDS needs special care and support, as does the family. The diagnosis of HIV or AIDS is described by Kagee (2008:247) as a traumatic stressor. Trauma can be described as "any circumstance that affects the body or psyche negatively" (Strydom \& Herbst, 2008:171). A diagnosis of HIV or AIDS can be categorised as such a circumstance. Such a situation can lead to withdrawal, a sense of helplessness, depression, fear or tension (Strydom \& Herbst, 2008:171). The hospice caregivers are trained in meeting the physical as well as psychosocial needs of families infected with, and affected by, HIV or AIDS in providing palliative care.

\section{THE HOSPICE PHILOSOPHY OF CARE}

Hospice care was established to provide palliative services for the dying and their families. Hospice is based on a philosophy of comprehensive care and it is not a facility that focuses solely on end-of-life care. End-of-life care can be defined as palliative care which is the active, comprehensive and interdisciplinary care of patients with an advanced, progressive and incurable disease. The World Health Organisation (WHO) defines palliative care as "an approach that improves the quality of life of patients and their families facing problems associated with life-threatening illness, through the prevention and relief of suffering, the early identification and impeccable assessment and treatment of pain and other problems - physical, psychosocial and spiritual" (Pretoria Sungardens Hospice, 2006:5).

Originally "to palliate" meant to cover with a cloak and in health care, where it is referred to as "palliative care", it would mean alleviating the symptoms of a disease without curing it (Corr, Nabe \& Corr, 1999:196, 199). Most hospices make use of the TLC model as described by Jerant, Azani, Nesbitt and Meyers (2004:56). This model is based on the letters T-L-C and is summarised in Table 1. 


\section{TABLE 1}

TLC MODEL OF PALLIATIVE CARE

\begin{tabular}{|c|l|l|}
\hline LETTER & MODEL ELEMENT & \multicolumn{1}{|c|}{ ELABORATION } \\
\hline $\mathrm{T}$ & Timely & $\begin{array}{l}\text { Proactive rather than reactive approach to avoid } \\
\text { prolonged unnecessary suffering. } \\
\text { Nurses, social workers, trained laypersons and others } \\
\text { involved. }\end{array}$ \\
\hline $\mathrm{L}$ & Longitudinal & $\begin{array}{l}\text { Balance of palliative and curative measures evolves } \\
\text { with time. }\end{array}$ \\
\hline $\mathrm{C}$ & $\begin{array}{l}\text { Collaborative } \\
\text { Comprehensive }\end{array}$ & $\begin{array}{l}\text { Patients, family members and providers share } \\
\text { decisions. } \\
\text { All empirically supported domains of palliative care } \\
\text { are addressed. }\end{array}$ \\
\hline
\end{tabular}

This model is based on holistic principles focusing on the patient as an individual within a family system and part of the broader community.

The general perception of medical care is to prevent death or to cure. In palliative care the focus is on maintaining quality of life, or slowing down the process of losing one's quality of life (Jerant $e t$ al., 2004:55). In the helping or caring relationship the aim of the caregivers will be to come alongside the patients and their families and offer the necessary support in dealing with the stressful situation caused by the sickness. The relationship itself is central to helping and it requires a certain number of skills to be developed in the caregiver such as empathy, good listening skills, a warm, caring attitude, and ability to identify and address needs. The ultimate goal of the helping relationship will be to help the patients to manage their lives better in order to have maximum quality of life as long as possible (Egan, 1994:47-48). Seen against this background it is important to refer to the continuum of palliative care, as illustrated in Figure 1.

This continuum can be applied to HIV and AIDS and includes the following:

- Counselling before and after voluntary HIV testing (Category 1 patients). Supporting people with HIV or AIDS who are not sick and their families (Category 1 patients and their affected families).

- Providing home-based care to people who are ill (Category 2 and 3 patients).

- Bereavement counselling and follow-up visits for affected families of dying patients, as well as support after the death of a patient (South Coast Hospice, 2003).

FIGURE 1

THE PALLIATIVE CARE CONTINUUM

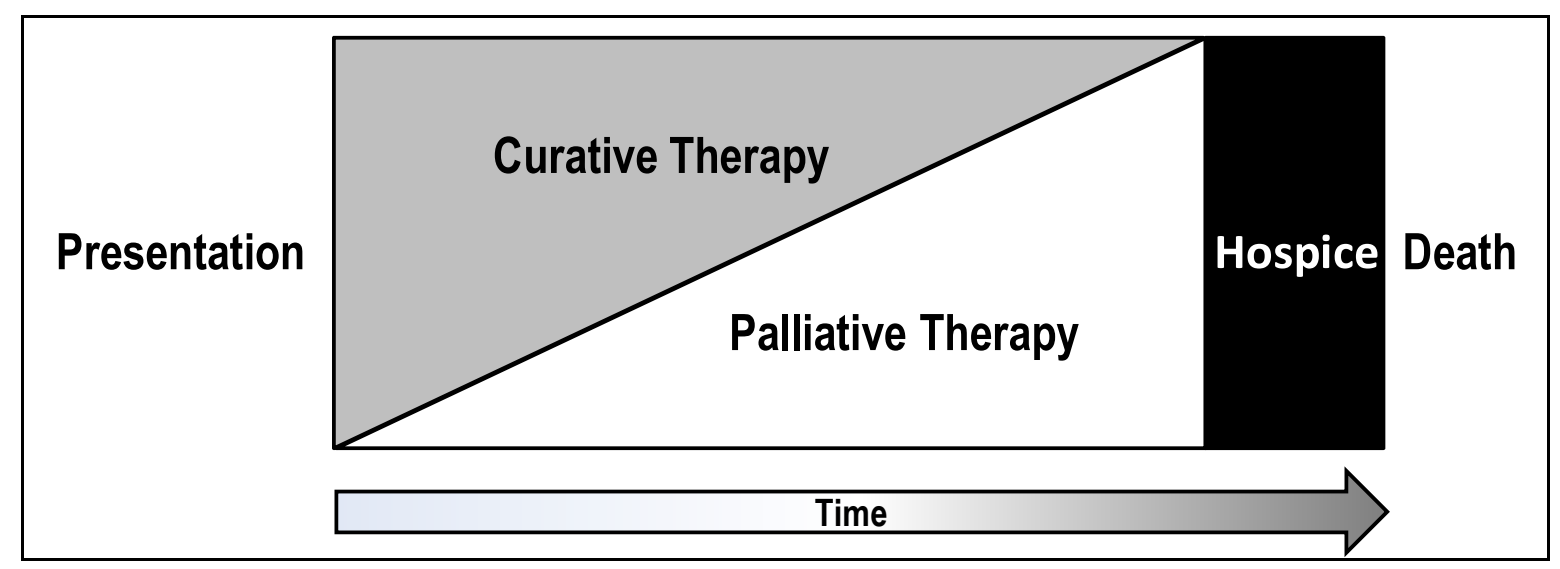


Figure 1 represents the continuum of care as described by Emanuel, Von Gunten and Ferris (1999:14). With the advancement of a terminal illness, the amount of curative therapy will decrease and palliative therapy will increase. In the last stage of the illness, hospice care will be very important (Jerant et al., 2004:55).

In rendering palliative care on this continuum, the following objectives serve as a guideline for hospice care at the Hospice TLC in Kokstad:

- To provide holistic care to all patients referred to TLC within its area of jurisdiction;

- To offer a support system to patients and their families during a patient's illness and into the bereavement period;

- To provide effective pain control;

- To enhance quality of life for patients and their families and to positively influence the course of a patient's illness;

- To provide trained caregivers to patients requiring full-time care;

- To provide ongoing training to caregivers so that they can be effective and efficient in administering care within the home-based care system;

- To apply multidisciplinary team approaches in addressing the needs of patients and their families;

- To regularly update palliative nurses on the AIDS programmes and treatments so that they can inform patients and refer appropriately;

- To assess the impact and effect of chronic illnesses (TB, cancer, pneumonia, malaria, PCP) to the target region and assist if possible;

- To provide the elderly with frail care services and a step-down facility from hospital back to the home, and to assist those who are ill in their places of residence and ensure the necessary care;

- To refer patients to social workers for the appropriate grants;

- To find placement for orphaned children through the assistance of Child Welfare S.A. Kokstad;

- To arrange for professional counselling for patients and their families;

- To promote AIDS awareness in its area of jurisdiction;

- To provide food parcels to families in need;

- To communicate with other organizations so as to complement one another and unite efforts;

- To offer training to other organisations (Calman, 1984:124; Hospice TLC Constitution, 2006).

The HIV and AIDS pandemic is posing new challenges to hospice care (Buckingham \& Meister, 2001:461). The tasks and roles of Hospice caregivers regarding HIV and AIDS need further exploration and discussion. 


\section{THE TASKS AND ROLES OF HOSPICE CAREGIVERS IN TERMS OF HIV AND AIDS}

\section{The home-based caregiver's scope of practice}

Caregivers at the Hospice TLC in Kokstad are practising as home-based caregivers. According to policy documents of the South Coast Hospice (2003), all actions and procedures of homebased caregivers are planned by a professional nurse and carried out under the supervision of a professional nurse. The scope of practice includes the following:

- Care of the patient according to a care plan;

- Promotion of health and maintenance of the hygiene of a patient or family and community;

- Promotion and maintenance of the physical comfort of a patient, comfort, rest, sleep, exercise and reassurance of the family;

- Prevention of physical deformities and other complications in a patient;

- Assessing patients in a critical condition, e.g. temperature, pulse and respiration, and report;

- Promotion and maintenance of body functions;

- Promotion and monitoring of nutrition for the patient and family;

- Promotion of communication with the patient and the family;

- Assist the professional nurse during nursing procedures;

- Care of a dying patient and recently deceased patient;

- Bereavement care for family/carers;

- Referring patients to clinic/hospital or community organisations;

- Networking with other members of the care team (South Coast Hospice, 2003).

From the above points it is clear that Hospice caregivers have the potential to play a vital role in meeting the needs of families infected with, or affected by, HIV and AIDS.

\section{The training of Hospice caregivers}

All Hospice caregivers are properly trained with regard to their scope of practice, the essentials of care and palliative care, and their specific roles in this regard. Caregivers at Hospice TLC undergo a 59-day basic training course in home-based care. This is followed up by a course on paediatric palliative care stretching across a period of two weeks. The focus is on the comfort of the patient and the support of the family. The following three important precepts of palliative caring form part of the training:

- Utilising interdisciplinary resources' strengths;

- Acknowledging and addressing the concerns of the caregivers;

- Building supportive mechanisms and systems (Groenewald, 2005:134).

\section{The roles of the caregiver}

The roles of the caregiver are highly appropriate in ensuring that the patient is comfortable and the family receives the necessary support by utilising the objectives of hospice care described earlier in this article. A number of specific roles can be fulfilled by the hospice caregiver in fulfilling the needs of the patient and the family. These roles include those of teacher, coordinator, mediator, communicator and collaborator (Danielson, Hamel-Bissell \& WinsteadFry, 1993:171). Each of these roles will be discussed briefly, namely those of teacher, coordinator, mediator, communicator and collaborator. 
The services provided by Hospice TLC caregivers adhere to the ethical code for nursing in general, where the aim is to focus on the wellbeing of patients; this is a commitment which shows respect for persons. Care shows that patients matter as individuals (Pera \& Van Tonder, 2005:5). In dealing with the patient it is important to remember that the needs, as well as the rights and choices of the mentally competent patient should be respected in the first place and not those of the family (Pretoria Sungardens Hospice, 2006:22).

\section{The tasks of hospice caregivers}

The hospice caregiver has several tasks with regard to people infected with, or affected by, HIV and AIDS. Their first task is to encourage voluntary testing and counselling at local clinics and to provide general health education. Support of infected people is advocated - not only support by their family, but also by the broader community (Mboyi, Carrara, Makaye, Frohlich \& Karim, 2005:10-17).

Hospice caregivers act as a valuable link between the medical staff actually communicating the diagnosis and the patient him/herself and the family. In breaking bad news to the patient, in this case the diagnosis of HIV or AIDS, special skills will be required of the communicator. The way that the patient responds to the news becomes a very crucial part of the interview. This interview comprises two phases: the sharing of the diagnosis with the patient, and dealing with his/her reaction to the news (Pretoria Sungardens Hospice, 2006:14).

The hospice caregivers assist in informing the family of the diagnosis, answering questions and giving more information, and communicating information and test results in a language understandable to the patient and the family (Pretoria Sungardens Hospice, 2006:20).

The hospice caregiver has a valuable role to fulfil when it comes to education and awareness regarding HIV and AIDS.

Once the diagnosis is shared and the initial shock is over, a plan of action needs to be formulated. A family meeting can be useful and should aim at:

- assessing the family system and dynamics;

- sharing their understanding of the diagnosis, prognosis and management goals;

- establishing an atmosphere of trust where feelings can be expressed freely;

- planning advance care;

- reconciling relationships, where needed; and

- establishing a sense of control (Calman, 1984:124-127).

After having been diagnosed with HIV or AIDS, people need help in coping with the psychosocial distress caused by the diagnosis.

Factors they consider stressful are the social stigma, living with their diagnosis and condition, as well as starting treatment (Kagee, 2008:249). Hospice caregivers act as a buffer between the patient and the community. Social stigma is still a huge problem within communities and ostracism is a real threat (Buckingham \& Meister, 2001:463). Both the patient and the family need ongoing support from the community they belong to. The Department of Social Development (2003:13) emphasises the importance of introducing patients and families to resources in the community.

Smit (2007:9) points out that family functions are affected by HIV and AIDS, which places an extra burden on family members. These burdens could be alleviated by making use of the circles of support model (Smart, 2003:46). The first circle would imply help from immediate family; the second circle would be help from the community, e.g. neighbours, and the third 
circle would include people in the broader society, e.g. church groups, local AIDS support groups, NGOs, e.g. the local hospice or CWFSA businesses and leaders. The integrated service delivery model makes provision for the development of strengths of the individuals, groups and communities by building their capacity for growth and development. This is called the development paradigm. The main aim with this approach is to enable communities to meet their own needs (Department of Social Development, 2003:11).

Hospice caregivers play a vital role in identifying the needs of patients and in enabling them to make use of relevant resources within the community to meet their needs (Smart, 2003:42). People living with HIV and AIDS, their families and their neighbours need more support than only health care (Groenewald, 2005:127).

The circles of support, as referred to by Smart (2003:43), are important when caring for families infected with, or affected by, HIV or AIDS. Three circles of support are mentioned:

- Help from immediate family and friends;

- Help from neighbours and the community;

- Resources in the broader society, such as Hospice and Child Welfare - South Africa.

Hospice caregivers resort under "Resources in the broader society".

\section{RESULTS}

\section{Focus group information}

All nine permanently employed hospice caregivers participated in five focus group sessions. These discussions were based on carefully formulated questions as described by Greeff (2007:308). A Xhosa interpreter assisted during the sessions to record communication. The duration of each session was approximately one hour.

The focus group discussions were based on the following questions:

- What basic information did the caregivers need to have before the onset of the research project?

- What are the caregivers' personal opinions of their role in the lives of families infected with, and affected by, HIV and AIDS?

- How do the caregivers see the needs of the families infected with or affected by HIV and AIDS?

- What was the outcome of the focus group sessions?

\begin{tabular}{|c|c|}
\hline $\begin{array}{l}\text { Focus group } \\
\text { session } 1\end{array}$ & $\begin{array}{l}\text { Goal: to communicate basic information regarding the research project to focus } \\
\text { group members }\end{array}$ \\
\hline Objectives & $\begin{array}{l}\text { - To make contact with caregivers. } \\
\text { - To explain the goals of the research project. } \\
\text { - To obtain written informed consent from the participants. }\end{array}$ \\
\hline $\begin{array}{l}\text { Course of the } \\
\text { focus group } \\
\text { session }\end{array}$ & $\begin{array}{l}\text { - This session was a contact/contract session. } \\
\text { - The researcher introduced herself and her assistant. } \\
\text { - The goals of the research project were stated. } \\
\text { - Informed consent was obtained in writing. } \\
\text { - The number and duration of focus group sessions were discussed. } \\
\text { - Ethical aspects were clarified. }\end{array}$ \\
\hline $\begin{array}{l}\text { Themes } \\
\text { emerging }\end{array}$ & $\begin{array}{l}\text { - Positive attitude towards the research project from the caregivers. } \\
\text { - Appreciation from the caregivers for an opportunity to vent their own feelings } \\
\text { regarding their work. }\end{array}$ \\
\hline
\end{tabular}




\begin{tabular}{|l|l|}
\hline $\begin{array}{l}\text { Examples of } \\
\text { responses }\end{array}$ & $\begin{array}{l}\text { "I occasionally feel despondent as a caregiver due to the fact that there is only so } \\
\text { much that I can do. The need is so huge. I appreciate you taking the time to listen } \\
\text { to us." }\end{array}$ \\
\hline $\begin{array}{l}\text { Correlation } \\
\text { with literature }\end{array}$ & $\bullet \begin{array}{l}\text { Guidelines for conducting focus group sessions, as described by Greeff, } \\
(2007: 300-311), \text { were utilised successfully. }\end{array}$ \\
\hline
\end{tabular}

\begin{tabular}{|c|c|}
\hline $\begin{array}{l}\text { Focus group } \\
\text { session } 2\end{array}$ & $\begin{array}{l}\text { "What are the caregivers' personal opinions regarding their role in the lives of } \\
\text { families infected with and affected by HIV and AIDS?" }\end{array}$ \\
\hline $\begin{array}{l}\text { Goals of focus } \\
\text { group session }\end{array}$ & $\begin{array}{l}\text { - To allow free discussion, facilitated by the interpreter, regarding the role of a } \\
\text { caregiver. } \\
\text { - To define the specific roles of caregivers with regard to people infected with, or } \\
\text { affected by, HIV or AIDS. }\end{array}$ \\
\hline $\begin{array}{l}\text { Course of } \\
\text { focus gro } \\
\text { sessions }\end{array}$ & $\begin{array}{l}\text { - Discussion on the caregivers' views of their own roles in meeting the needs of } \\
\text { their patients, together with their affected families. } \\
\text { - This session was a lively discussion on the work done by the caregivers. }\end{array}$ \\
\hline & $\begin{array}{l}\text { - Support is important for patient and family within their community. } \\
\text { - It takes time to build the caring relationship, but it pays off in the long run. } \\
\text { - Caregivers need support and guidance for themselves to prevent compassion } \\
\text { fatigue. } \\
\text { - Caregivers act as a link between the patient and the resources in the community. } \\
\text { - Caregivers fulfil different roles in meeting the needs of their patients and their } \\
\text { affected families. }\end{array}$ \\
\hline $\begin{array}{l}\text { Exa } \\
\text { resp }\end{array}$ & $\begin{array}{l}\text { - "We are always with sick people, even in our own families and communities. We } \\
\text { become very tired of the sickness." } \\
\text { - "We want to help sick people who need support. We want to advise and educate } \\
\text { them to have hope again." } \\
\text { - "We would like to act as someone objective and supportive who will not judge } \\
\text { them for our patients and their families." } \\
\text { - "There is still a lot of stigma in our communities, especially from the churches." } \\
\text { - "Our patients need love and understanding. Sometimes they are neglected by } \\
\text { their own family." } \\
\text { "The people are hungry. We help with food parcels, cooking and veggie } \\
\text { gardens." }\end{array}$ \\
\hline $\begin{array}{l}\text { Correlation } \\
\text { with literature }\end{array}$ & $\begin{array}{l}\text { - The caregivers' scope of practice (South Coast Hospice, 2003) gives good } \\
\text { guidelines for the service they render. } \\
\text { - They are fulfilling the roles of teacher, coordinator, mediator, communicator and } \\
\text { collaborator successfully (Danielson et al., 1993:171). } \\
\text { - Caring is the cornerstone of their service rendering (Pera \& Van Tonder, 2005:6). }\end{array}$ \\
\hline
\end{tabular}

\begin{tabular}{|l|l|}
\hline $\begin{array}{l}\text { Focus group } \\
\text { session } 3\end{array}$ & $\begin{array}{l}\text { "How do the caregivers see the needs of the families infected with, or affected } \\
\text { by, HIV and AIDS?" }\end{array}$ \\
\hline Goal & $\begin{array}{l}\text { To determine how the caregivers see the needs of their patients together with } \\
\text { those of their affected families. }\end{array}$ \\
\hline $\begin{array}{l}\text { Course of the } \\
\text { focus group } \\
\text { session }\end{array}$ & $\begin{array}{l}\text { An open discussion was held during which the caregivers shared their views on } \\
\text { the needs of their patients and their affected families as they interpret them. }\end{array}$ \\
\hline $\begin{array}{l}\text { Themes } \\
\text { emerging }\end{array}$ & $\begin{array}{l}\text { Their training as hospice caregivers enables them to identify the needs of their } \\
\text { patients and their affected families. } \\
\text { The needs of the patients vary in accordance with the stages of their illness. }\end{array}$ \\
\hline
\end{tabular}




\begin{tabular}{|c|c|}
\hline & $\begin{array}{l}\text { They distinguished three categories of patients: one, still able to function fairly } \\
\text { normally two, more dependent on others and chronically ill and three, being } \\
\text { terminally ill. } \\
\text { - They act as a link between the needs of patients and affected families and } \\
\text { relevant resources in the community. } \\
\text { - The support they give to their patients and their affected families is vitally } \\
\text { important. } \\
\text { - Currently they do not have the time to do memory work or run support groups. }\end{array}$ \\
\hline $\begin{array}{l}\text { Examples of } \\
\text { responses }\end{array}$ & $\begin{array}{l}\text { - "The patients and their families don't have identity documents, therefore cannot } \\
\text { get the grants, so they are hungry." } \\
\text { - "The families need information on HIV/AIDS to understand it better and not } \\
\text { stigmatise the patients." } \\
\text { - "There is a need for support and for opportunities to disclose." } \\
\text { - "The patients need to have hope." }\end{array}$ \\
\hline $\begin{array}{l}\text { Correlation with } \\
\text { literature }\end{array}$ & $\begin{array}{l}\text { - Their training enables the caregivers to be competent in addressing the needs of } \\
\text { their patients and their affected families. } \\
\text { - Through this knowledge they are enabled to draw up a proper care plan which } \\
\text { is evaluated from time to time (Slabbert, 2003:23-24). }\end{array}$ \\
\hline
\end{tabular}

\begin{tabular}{|c|c|}
\hline $\begin{array}{l}\text { Focus group } \\
\text { session } 4\end{array}$ & $\begin{array}{l}\text { "How do the objectives of Hospice TLC as stated in their constitution, and } \\
\text { actual service rendering compare with each other?" }\end{array}$ \\
\hline Goal & $\begin{array}{l}\text { - To determine how the caregivers see their service rendering as outlined by the } \\
\text { objectives of Hospice TLC as stated in their constitution. }\end{array}$ \\
\hline $\begin{array}{l}\text { Course of the } \\
\text { focus group } \\
\text { Session }\end{array}$ & $\begin{array}{l}\text { - Each caregiver received a copy of the objectives. The group discussed the } \\
\text { objectives individually to determine to what measure they were reaching } \\
\text { these objectives. }\end{array}$ \\
\hline Objective 1 & $\begin{array}{l}\text { Follow a holistic approach in meeting the needs of patients and their } \\
\text { families. }\end{array}$ \\
\hline $\begin{array}{l}\text { Exar } \\
\text { resp }\end{array}$ & $\begin{array}{l}\text { - "Yes, we do follow a holistic approach by addressing emotional, physical and } \\
\text { social needs. We treat the person as a whole human being. When it comes to } \\
\text { spiritual needs, we prefer to refer patients to their priests, pastors and } \\
\text { ministers of the churches they belong to." }\end{array}$ \\
\hline Obje & port to patients and their families during bereavement. \\
\hline $\begin{array}{l}\text { Exar } \\
\text { respc }\end{array}$ & $\begin{array}{l}\text { - "We do give a lot of support, even pay one visit after a patient has died to do } \\
\text { bereavement counselling. The number of visits will depend on the family's } \\
\text { needs and the type of relationship they had before the patient passed away". }\end{array}$ \\
\hline Obje & To provide effective pain control. \\
\hline $\begin{array}{l}\text { Examples of } \\
\text { responses }\end{array}$ & $\begin{array}{l}\text { - "As caregivers we are not allowed to give any tablets for pain management, } \\
\text { only registered nurses may administer medicine. It includes Morphine, } \\
\text { Panado and Ibuprofen". }\end{array}$ \\
\hline Objec & To provide trained caregivers to patients requiring ongoing care. \\
\hline $\begin{array}{l}\text { Example of } \\
\text { responses }\end{array}$ & $\begin{array}{l}\text { - "We are all trained and still receive training on a weekly basis. We would like } \\
\text { more training on trauma counselling and cancer management". }\end{array}$ \\
\hline Objective 5 & To provide food parcels to needy families. \\
\hline $\begin{array}{l}\text { Example of } \\
\text { responses }\end{array}$ & $\begin{array}{l}\text { - "The food parcels are very important and sometimes it is the only food in the } \\
\text { home. The children are so glad to see us, for they know we come to help } \\
\text { them". }\end{array}$ \\
\hline Themes & followed in meeting the physical and psychosocial \\
\hline
\end{tabular}




\begin{tabular}{|c|c|}
\hline emerging & $\begin{array}{l}\text { - Support is given by means of visits, depending on individual needs. They also } \\
\text { provide bereavement support. } \\
\text { - Pain management is addressed in a professional manner. } \\
\text { - Ongoing training for the caregivers is a need, as well as support and } \\
\text { debriefing opportunities through supervision. } \\
\text { - Awareness campaigns regarding relevant issues, e.g. cancer as an } \\
\text { opportunistic infection, should be addressed. } \\
\text { - Material needs are prevalent, e.g. the need for food parcels, clothing and help } \\
\text { in obtaining relevant documentation with a view to obtaining access to grants. } \\
\text { - There is a need to communicate effectively with other service rendering } \\
\text { organisations, e.g. Child Welfare SA - Kokstad and Khanyeselani. } \\
\text { - They have been involved in the training of staff attached to other } \\
\text { organisations, e.g. Lusikisiki Hospice. }\end{array}$ \\
\hline $\begin{array}{l}\text { Correlation with } \\
\text { literature }\end{array}$ & $\begin{array}{l}\text { - The objectives, as stated in the constitution of Hospice TLC (2006), were } \\
\text { used as guidelines for the fourth focus group discussion. According to the } \\
\text { participants' feedback and discussion, it was clear that these objectives were } \\
\text { followed with regard to service delivery. }\end{array}$ \\
\hline
\end{tabular}

\begin{tabular}{|c|c|}
\hline $\begin{array}{l}\text { Focus group } \\
\text { session } 5\end{array}$ & "What was the outcome of the focus group sessions?" \\
\hline Goals & $\begin{array}{l}\text { - To give feedback to the caregivers on the outcome of the previous four focus } \\
\text { group sessions. } \\
\text { To lay the ground for the next phase of the research project. (It was not a } \\
\text { termination session). }\end{array}$ \\
\hline $\begin{array}{l}\text { Course of the } \\
\text { focus group } \\
\text { session }\end{array}$ & $\begin{array}{l}\text { - The themes as they emerged during the group sessions were discussed with } \\
\text { the caregivers. This seems to have the effect of enlightening them regarding } \\
\text { the value of their service rendering. The researcher praised them for their } \\
\text { caring, supportive attitude towards their patients and their affected families. } \\
\text { This acted as a motivator to continue their services. They appreciated the time } \\
\text { the researcher spent with them and were keen to form part of further research. } \\
\text { Being able to speak Xhosa allowed for freer communication. }\end{array}$ \\
\hline $\begin{array}{l}\text { Themes } \\
\text { emerging }\end{array}$ & $\begin{array}{l}\text { - A good working relationship was established between the researcher and the } \\
\text { caregivers, paving the way for further research. } \\
\text { - To them, receiving the feedback shed more light for them on the value of the } \\
\text { service they render. } \\
\text { - The feedback seems to motivate them for further service rendering. } \\
\text { - Making use of an assistant who is fluent in Xhosa allowed for the caregivers } \\
\text { to communicate freely. }\end{array}$ \\
\hline $\begin{array}{l}\text { Correlation with } \\
\text { literature }\end{array}$ & $\begin{array}{l}\text { - Being aware of cultural differences and communication challenges where } \\
\text { English is not the respondents' first language should be taken into account } \\
\text { (De Vito, 2001:69, 139). } \\
\text { - This was addressed with the aid of an assistant who is fluent in Xhosa. At the } \\
\text { end of this session the facilitator summarised the main viewpoints, verified } \\
\text { them and expressed her gratitude for the respondents' participation (Greeff, } \\
\text { 2007:311). }\end{array}$ \\
\hline
\end{tabular}




\section{DISCUSSION OF THE RESULTS}

With the Home-based Caregiver's Scope of Practice, as compiled by South Coast Hospice (2003), the caregivers have good guidelines to meet the needs of their patients and their affected families.

The researcher noticed five roles the caregivers fulfil while rendering services within their communities, namely those of teacher, coordinator, mediator, communicator and collaborator (Danielson et al., 1993:171). They work under the supervision of two registered nurses who help them draw up care plans for each individual patient along with his/her family. They perform their duties against the background of general hospice and nursing ethics. Caring is regarded as the cornerstone of all nursing, which is centred on the wellbeing of the patient. It is a commitment which entails respect for all persons.

"Caring means patients matter as persons" (Pera \& Van Tonder, 2005:6). Competencies of caring are manifested as follows:

- Having knowledge of the situation impacting on the patient in all its diversity and knowing how to address it;

- Implementing a care plan based on the knowledge obtained by good training;

- Evaluating the care plan/actions (Slabbert, 2003:23-24).

In caring for the patients, three categories are distinguished in patient care.

\section{Category 1 Patients}

These patients are not sick; they may be working, attending a support group or receiving ARV support. They could be making contact with a trained member of the care team at least once a month. This contact could be on a one-on-one basis or as part of a support group.

\section{Category 2 Patients}

These patients would need some medical/nursing care in addition to psychosocial care. Weekly visits from a caregiver would be needed as well as medical attention from an appropriate professional once a month.

\section{Category 3 Patients}

At this stage the patient is home or bed-bound, needing significant clinical care. Caregivers need to pay at least two visits per week, of which one must be with a professional nurse. These visits occur on a one-on-one basis (South Coast Hospice, 2003). The objectives set by Hospice TLC together with the Home-based Caregiver's Scope of practice, as compiled by South Coast Hospice, serve as very clear goals in service rendering by the TLC caregivers. During the fourth focus group session the service rendering was evaluated in terms of these goals. The caregivers were in agreement that they are reaching their goals in meeting the needs of their patients, as well as those of the affected family members.

Caring involves stepping out of one's own personal frame of reference into that of the others. "To care is to act not by a fixed rule, but by affection and regard" (Slabbert, 2003:24). Caring would be the main attribute of the TLC caregivers, and in building the caring relationship it would be expected that they would show certain characteristics such as warmth, respect, consideration and maintenance of confidentiality, knowledge and the ability to listen.

The patient must experience sincerity in the caregiver's attitude in building a helping relationship. Through this relationship the patient and affected family are enabled to explore the 
impact the sickness has on them, clarify feelings and gain insight into the distressing situation caused by the sickness (Johnson, 2000:214).

Through their training the caregivers are able to identify the impact of the diagnosis of a terminal disease such as HIV and AIDS on their patients and their affected families. Kagee (2008) defined the diagnosis of HIV and AIDS as a traumatic stressor. This could result in emotions of anger and depression as a result of the experience of trauma after the diagnosis. Common symptoms of depression would be:

- sadness;

- feeling of hopelessness or pessimism;

- feelings of guilt, worthlessness or helplessness;

- loss of interest in things the person previously enjoyed;

- concentration problems;

- sleep disturbances: Sleep too much or too little;

- loss of appetite or eating too much;

- weight loss;

- fatigue;

- restlessness, irritability, agitation;

- physical symptoms, e.g. headaches, digestive problems;

- low self-esteem;

- suicidal thoughts or attempts (Iverson, 2007:11).

Chronic illness challenges the ability of the individual patient as well as the affected family. Under such circumstances the family's ability to communicate effectively, to do problemsolving and to display their internal strengths and the durability of the family unit comes under strain. The illness acts as the stressor and the affected family needs social support. Community resources and support include all individuals and institutions that the family could use to cope with the stressor situation (Danielson et al., 1993:46-47).

The Hospice TLC caregiver is part of the social support system. In the caring relationship issues such as maintaining the dignity and self-respect of a patient are often more important to the patient than symptom management such as pain relief. For the caregiver it is a challenge to be sensitive to the patient's needs to such an extent that there would be a balance between remaining life as well as possible managing and preparing for approaching death. In dealing with grief, which can start before death with a diagnosis, it is important to understand that grief responses are characterised by individual differences (Costa, Hall \& Stewart, 2007:29).

In dealing with their patients and their affected families, the TLC caregivers manage to meet these individual differences in dealing with trauma and grief. The outcome of the 5 focus group sessions will be discussed in terms of these roles as outlined by Danielson et al. (1993:171).

\section{Teacher}

An affected family's need for information regarding the condition, prognosis, progress and comfort of their ill loved one should not be underestimated. They wish to be informed at an understandable level. The information should be given in a trusting, helping relationship with a warm, caring attitude and with respect. Honesty and acceptance are very important (Danielson et al., 1993:170). By broadening the affected family's and community's base of information, 
they become empowered (Delport, Roux \& Rankin, 2008:318). From the focus group sessions it became clear that the TLC caregivers are fulfilling the role of teachers and educators; they act as a link between professional medical staff and manage to communicate knowledge in clear, understandable terms with empathy. Cultural differences need to be taken into account as different cultures view self-disclosure differently (De Vito, 2001:69, 123, 139). The Hospice TLC caregivers are mostly Xhosa first-language speakers who are familiar with the Xhosa culture. The majority of patients are Xhosa. There is one white English-speaking caregiver and two white English-speaking professional nurses who act as supervisors. By means of their training they have the knowledge to educate the people regarding issues such as voluntary testing, grants, material assistance, documentation and resources within the community. Stigmatisation regarding HIV and AIDS is still a reality. Misconceptions still exist, and with caregivers fulfilling the role of educator, this should change in the course of time (Halkett, 2005:61). Families need information to plan realistically, especially where children are concerned. Should a mother be terminally ill, it is important for all parties involved to be part of the planning of future orphan care. With regular visits to the affected households, they have an opportunity to give guidance regarding good nutrition and living a healthy lifestyle, e.g. prevention of HIV infection.

Poverty is the biggest problem; therefore the caregivers supply the affected families with at least one food parcel per week. By doing this they build a positive relationship with the families. It is especially the children who look forward to their visits. Caregivers assist with the preparation of meals and teach the older children how to cook and to prepare gardens. Because of the sickness of the primary caregiver, the youngsters are not taught traditions and skills, e.g. cooking, crafts and gardening (Villarreal, 2002:1, 2).

Children often experience compromised parenting and witness debilitating illness (Wood, Chase \& Aggleton, 2006:1924). The caregiver, who has built up a good relationship with the family, would be able to come alongside the children to support them, answer their questions, teach them skills and help them build their resilience. This is very important, especially for vulnerable children. Resilience could be described as the human capacity to face, overcome and be strengthened or even be transformed by the adversities of life.

This is a key concept in the way households deal with being affected by HIV/AIDS. Although all children pay a price in living with, or losing a parent to, HIV/AIDS, it should not necessarily cause developmental or psychological harm to the children affected (German, 2005:42).

The presence of a Hospice TLC caregiver in the lives of Orphans and Vulnerable Children (OVC) and their families means that the resilience of these affected families can be built up, enabling them to cope better with the challenges they face. Caregivers educate them regarding the availability of grants, e.g. disability, foster care, care dependence, old age pensions and child-support grants in order to meet their material needs (Halkett, 2005:227).

One of the biggest obstacles in obtaining the grants is the unavailability of the relevant documents. The caregivers assist them by referring them to social workers (Halkett, 2005:223).

As a teacher, the TLC caregiver could involve the terminally ill patient together with his/her affected family members in memory work. Some orphans experience distress by not having any momentous or tangible reminders of their lives with their parents. This results in an extreme sense of loss (Wood et al., 2006:1925). 
By deliberately setting up a safe space for the telling of a life story, parents and children can be engaged in using memory work as a communication tool (German, 2006:45). In practice the caregivers do not have time to do this and the help of volunteers could be called upon to assist with this valuable project of memory work. They do encourage their patients to have memory boxes and get their wills and documentation in order. They also encourage members of the community to go for voluntary STD, TB and HIV and AIDS testing, as well as to stick to their ARV programmes. They encourage their patients to go to the clinics on a regular basis for CD4 count blood tests.

\section{Coordinator}

Caregiving efforts need to be coordinated o strengthen communication lines within families, to decrease anxiety and to improve problem solving. Hospice TLC caregivers play a vital role as coordinators. By building a relationship marked by trust, support and coordination of services, the affected family's increased stress levels and sense of disorder could be minimised.

With the TLC caregivers' involvement over the last two years, it is evident that the needs of terminally ill patients and their families have been efficiently addressed. Rendering support on an ongoing basis decreases the patient's and affected family's sense of bewilderment as a result of the trauma of the diagnosis. The caregivers form a valuable link between other resources and members of the multidisciplinary team (Jerant et al., 2004:56).

\section{Mediator}

As a mediator, the Hospice TLC caregiver also plays an important role. The HIV and AIDS patients might initially only confide in the caregiver, lacking the courage to disclose to their family, neighbours or the community (Wood et al., 2006:1924).

The mediator helps by facilitating anticipatory mourning, by assisting family members to maintain a sense of mastery, integrity, cohesiveness, identity and open communication lines (Danielson et al., 2007:171).

\section{Communicator}

As communicators, the Hospice TLC caregivers play a vital role. Through research it was found that teenagers prefer to be told the truth about the sickness of their parents. In African cultures children are simply told that a person who died "went away". Death is considered an inappropriate topic for discussion with children. Through contact with the affected families they are able to communicate their needs to the appropriate individuals and resources within the community.

Because of the stigmatisation, AIDS-related death is often considered to be a "bad death". People tend to link it in their minds to shameful, unacceptable sex, as well as to moral dangers and the political transitions of modern life.

Within the African context children display a tendency to show signs of internalising grief by falling into a state of depression, withdrawal and failure to thrive. The opposite also happens when children start with acting-out types behaviour by becoming angry, rebellious and disruptive (Wood et al., 2006:1924-1925).

Through their training, Hospice TLC caregivers are equipped to deal with these cultural issues in which certain topics such as death are taboo, as well as to encourage family members to have open communication lines. They are able to identify possible warning signs of children being neglected, abused or made vulnerable because of the impact of the sickness. 
The Hospice TLC caregivers have a great sense of loyalty and commitment to the patients and families they deal with. They fulfil the role of collaborator by working together with their patients and families. According to them, it takes an average of 16-18 months to build a strong relationship of trust. All of the caregivers have experienced loss in their own lives, which enables them to show empathy to the people they deal with. They have persevered over the last two years and are presently experiencing a great sense of fulfilment and job satisfaction. They are working as volunteers for an NPO and their main aim is not to work for monetary reward, but to help people in their own communities who are in need. The patients and their families confide in them regarding their fears, doubts and worries. The children bond with them and are glad to see them. They support the primary caregivers. Often a granny is not only caring for the patient, but also for the rest of the family.

To offer realistic hope and relief from anxiety, caregivers need to understand what the sickness means to the family. Ongoing training is necessary in order to increase their knowledge of the needs of the infected and affected people they deal with. They should encourage the family to mobilise their social support network to help relieve strain and stress (Danielson et al., 1993:172-173). The caregivers themselves need support to prevent burnout and compassion fatigue. They experienced the loss of one TLC caregiver during 2007 as a result of HIV and AIDS, which was very traumatic.

The researcher pointed out to them during the focus group sessions that they cannot bear all the responsibilities of support themselves. They need to refer the patients with their affected families to relevant individuals and resources within the community, as suggested by Danielson et al. (1993:66).

Living with hope is more positive than constantly thinking of dying of HIV and AIDS. This is the attitude the Hospice TLC caregivers are installing in the people they deal with.

To live with hope means:

- Most people infected with HIV are well and could live a good life some years after being infected;

- During this period adults and children with HIV can live active productive lives;

- They need support, advice and counselling to be able to look forward to several years of normal life;

- The surrounding community should be a source of love, care and support;

- Communities need to be encouraged to realise their potential (Halkett, 2005:81).

\section{Discussion}

After the diagnosis of HIV infection, people need help in coping with psychological distress. To live with the condition, receive treatment and deal with the social stigma they need support (Kagee, 2008:249). HIV and AIDS are regarded as stressors. The affected family needs to adapt to the new situation in which they also need support (Danielson et al., 1993:66).

The role of the caregivers working for Hospice TLC would be to give the needed support. This happens through the caregivers gaining entry to the affected families by taking care of the infected patient (Smit, 2007:2). Through palliative care the needs of the patient are addressed (Corr et al., 1999:186). With the circles of support (Smart, 2003:43) in mind, the caregivers enable the infected patients together with their affected families to make use of resources 
within the community to address their needs and to increase community support for families infected with, or affected by, HIV and AIDS.

\section{CONCLUSIONS}

- Through their training, the Hospice TLC caregivers are equipped to render support and care to patients and families infected with, or affected by, HIV and AIDS. This also gives them an appreciation of the research process, resulting in good cooperation between the researcher and the caregivers.

- They act as a valuable link between professional medical staff and the patients and their families. They are able to communicate information at an understandable level. They are also aware of the cultural context in which the patients and families are functioning, enabling them to "come alongside" the patients and their affected families in a meaningful, supportive manner.

- As teachers/educators they can help to clarify misconceptions about HIV and AIDS, and can help to minimise stigmatisation.

- In addressing material needs, they provide regular food parcels, assist with families obtaining relevant grants and educate families with regard to good nutrition and living healthy lifestyles.

- They manage to link up needy families with relevant resources within the community and educate them on the availability of resources.

- They motivate the patients to adhere to the ARV treatment programme.

- They assist with planned orphan care by helping the patients to get all the relevant documentation in order and referring them to the appropriate facilities in the community.

- Memory work does not receive the necessary attention because of the caregivers' very busy working schedules. Volunteers could be co-opted to assist with doing memory books and preparing memory boxes.

- No support groups are in operation. This should receive attention in future. They could also be run by volunteers.

- Caring for the carers needs special attention to assist them with debriefing and bereavement counselling. They could easily suffer from burnout or compassion fatigue.

- The caregivers have been in the field for approximately two years. They experience a deep sense of loyalty and commitment towards the patients and families they deal with.

- As volunteers they do not work for big monetary rewards. They receive a stipend if it is available. Care needs to be taken that good incentives are in place to keep them motivated to remain in the service of Hospice TLC, Kokstad, e.g. to improve their qualifications, or arranging a function in appreciation of their jobs well done.

- In motivating people for voluntary counselling and testing, it was found that they would rather go for tuberculoses (TB) testing as there are fewer stigmas associated with TB than with HIV and AIDS.

- The caregivers experience that churches are still very judgmental towards people infected with HIV and AIDS.

- After persevering in their jobs for two years as caregivers, they are now experiencing job satisfaction and fulfilment. 


\section{RECOMMENDATIONS}

Through their training the caregivers have an appreciation of the research project and were thus cooperative. Further training on a regular basis is recommended within the community for them to be able to meet the needs of the families they deal with.

- Material needs are the most prominent and it is recommended that regular food parcels be made available for distribution among needy families.

- As educators, they should continue to help minimise misconceptions and eliminate the stigma within the community, and encourage adherence to the ARV programme.

- Children at risk of being orphaned should be referred to relevant resources and be part of planned orphan care.

- Volunteers could be trained to assist with memory work and support groups.

- Special attention and support should be given to the caregivers to prevent burnout or compassion fatigue.

- From this research it is clear that the Hospice TLC caregivers fulfil a vital role in meeting the psychosocial needs of families infected with, or affected by, HIV and AIDS in the Kokstad area and they should be assisted by being referred to the relevant resources. Therefore it is recommended that the following aspects receive attention through further research:

- The identification of the bio-psychosocial needs of these infected or affected families;

- The improvement of service rendering to these families by utilising their circles of support.

\section{REFERENCES}

AVERT, 2005. South Africa HIV/AIDS Statistics. [Online] Available: http:www.avert. org/safricastats.htm [Accessed: 15/07/2008].

BOOYSEN, F. 2004. Social grants as safety net for HIV/AIDS affected households in South Africa. Journal of Social Aspects of HIV/AIDS research Alliance, 1(1):45-54.

BUCKINGHAM, R.W. \& MEISTER, E.A. 2001. Hospice care for the child with AIDS. The Social Science Journal, 38:461-467.

CALMAN, K.C. 1984. Quality of life in cancer patients - a hypothesis. Journal of Medical Ethics, (10):124-127.

CORR, C.A., NABE, C.M. \& CORR, D.M. 1999. Death and dying, life and living. United States: Thomson Wadsworth.

COSTA, B.M., HALL, L. \& STEWART, J. 2007. Qualitative exploration of the nature of griefrelated beliefs and expectations. Omega, 55(1):25-35.

DANIELSON, R.N., HAMEL-BISSELL, B. \& WINSTEAD-FRY, R.N. 1993. Families, health \& illness: perspectives on coping and intervention. St. Louis: Mosby.

DELPORT, J., ROUX, A. \& RANKIN, P. 2008. Die rol van maatskaplike werk in verwante pleegsorgplasings. Social Work/Maatskaplike Werk, 44(3):307-322.

DEPARTMENT OF SOCIAL DEVELOPMENT. 2003. National guide-lines for social services to children infected and affected by HIV/AIDS. Save the Children, South African Programme. 
DE VITO, J.A. 2001. The interpersonal communication book. New York: Longman.

EGAN, G. 1994. The skilled helper. Pacific Grove: Brookes/Cole.

EMANUEL, L.L., VON GUNTEN, C.F. \& FERRIS, F.D. 1999. EPEC - Education for Physicians on End-of-life Care: Participant's Handbook Plenary 3. Elements and models of end of life care. EPEC Project. The Robert Wood Foundation. USA. 1-15.

FOUCHÉ, C.B. \& DELPORT, C.S.L. 2007. Introduction to the research process. In: DE VOS, A.S., STRYDOM, H., FOUCHÉ, C.B. \& DELPORT, C.S.L. (eds) Research at grass roots: for the social sciences and human service professions. Pretoria: Van Schaik Publishers: 7185 .

FOUCHÉ, C.B. \& DE VOS, A.S. 2007. Problem formulation. In: DE VOS, A.S., STRYDOM, H., FOUCHÉ, C.B. \& DELPORT, C.S.L. (eds) Research at grass roots: for the social sciences and human service professions. Pretoria: Van Schaik Publishers: 100-110.

GERMAN, S.E. 2005. I am a hero - orphans in child-headed households and resilience. Pretoria: UNISA. (DLitt et Phil in development studies)

GREEFF, M. 2007. Information collection: interviewing. In: DE VOS, A.S., STRYDOM, H., FOUCHÉ, C.B. \& DELPORT, C.S.L. (eds) Research at grass roots: for the social sciences and human service professions. Pretoria: Van Schaik Publishers: 286-313.

GROENEWALD, M. 2005. Nursing and health-care issues from the beginning of life in adolescence. In: PERA, S.A. \& VAN TONDER, S. (eds) Ethnics in health care. Landsdowne: Juta: 111-137.

HALKETT, R. 2005. National programme: HIV/AIDS and the care of children. Johannesburg: Child Welfare South Africa.

HOSPICE TLC 2006. Constitution, Kokstad: Unpublished policy document.

IVERSON, K.M. 2007. Understanding trauma. In: FOLLETTE, V.M. \& PISTORELLA, J. (eds) Finding life beyond trauma. Oakland: New Harbinger: 9-25.

JERANT, A.F., RABMAN, S.A., NESBITT, T.S. \& MEYERS, F.J. 2004. The TLC model of palliative care in the elderly: Preliminary application in the assisted living setting. Annals of Family Medicine, 2(1):54-60.

JOHNSON, D.W. 2000. Reaching out. Boston: Allyn and Bacon.

KAGEE, A. 2008. Theoretical concerns in applying the diagnosis of PTSD to HIV and AIDS. Social Work/Maatskaplike Werk, 44(3):247-250.

MBOYI, L., CARRARA, H., MAKAYE, G., FROHLICH, J. \& KARIM, Q.A. 2005. Understanding HIV and AIDS stigma and discrimination at a community level: perspectives from rural KwaZulu-Natal. Fitzroy Victoria, Australia: Oxfam.

MOUTON, J. 2005. How to succeed in your master's and doctoral studies. Pretoria: Van Schaik Publishers.

OSD (Oxford Student Dictionary). 2001. Collaborator. Oxford: Clarendon Press.

PERA, S.A. \& VAN TONDER, S., 2005. Ethics in health care. Landsdowne: Juta.

PRETORIA SUNGARDEN'S HOSPICE. 2006. Module 2. Pretoria: HPCA.

SLABBERT, S. 2003. Caring: a nurse's perspective. Health Annals, 12:23-26. 
SMART, R. 2003. Children affected by HIV/AIDS in South Africa: a rapid appraisal of priorities, policies and practices. Arcadia: Save the children (UK).

SMIT, E. 2007. The impact of HIV/AIDS on rural South African families. Child Abuse Research in South Africa, 8(1):1-10.

SOUTH COAST HOSPICE. 2003. Scope of practice. Unpublished policy document.

STATSSA. 2008. Census 2001 - Municipality of Kokstad. [Online] Available: http:www. statssa.gov.za/extract.htm [Accessed: 21/07/2008].

STRYDOM, H. 2000. Maatskaplike navorsing diktaat vir MWKG 321-411. Potchefstroom: Potchefstroom Universiteit vir Christelike Hoër Onderwys.

STRYDOM, H. \& HERBST, A. 2008. The Psychosocial implications of the closing of a mine for workers and their families. Social Work/Maatskaplike Werk, 44(2):170-188.

TESCH, R. 1990. Qualitative research: analysis types \& software tools. Basingstoke: The Falmer Press.

VAN WYK, N. \& LEMMER, E. 2007. Redefining home-school-community partnerships in South Africa in the context of the HIV/AIDS pandemic. South African Journal of Education, 27(2):240-250.

VILLARREAL, M. 2002. HIV/AIDS: a rural issue. [Online] Available: http:www.fao. org/FOCUS/E/aids/aids 1-e.htm [Accessed: 21/07/2008].

WOOD, K., CHASE, E. \& AGGLETON, P. 2006. Telling the truth is the best thing: Teenage orphan's experiences of parental AIDS-related illness and bereavement in Zimbabwe. Social Science \& Medicine, 63:1923-1933.

Ms Nerina Bester, Child Welfare South Africa (Kokstad); Dr Alida Herbst, Social Work Division, School for Psycho-social Behavioral Sciences, North-West University, Potchefstroom Campus, South Africa. 